\title{
Liquid Corn and Fish Fertilizers Are Good Options for Fertigation in Blackberry Cultivars Grown in an Organic Production System
}

\author{
Javier Fernandez-Salvador ${ }^{1}$ and Bernadine C. Strik ${ }^{2,3}$ \\ Department of Horticulture, Oregon State University, 4017 ALS, Corvallis, \\ OR 97331
}

\author{
David R. Bryla \\ U.S. Department of Agriculture, Agricultural Research Service, Horticultural \\ Crop Research Unit, 3420 NW Orchard Avenue, Corvallis, OR 97330
}

Additional index words. Rubus, corn steep liquor, fish emulsion, hydrolysate, machine harvest, soil, tissue nutrients, drip, fertilizer injection, fruit quality

\begin{abstract}
The impact of organic fertilizer source on the growth, fruit quality, and yield of blackberry (Rubus L. subgenus Rubus Watson) cultivars (Marion and Black Diamond) grown in a machine-harvested, organic production system for the processed market was evaluated from 2011 to 2013. The planting was established in Spring 2010 using approved practices for organic production and was certified in 2012. Plants were irrigated using a dripline under a woven polyethylene groundcover (weed mat) installed for weed management. Two sources of liquid fertilizer were evaluated: 1) a corn steep liquor and fish waste digestion blend ("corn"; $2.5 \mathrm{~N}-1.1 \mathrm{P}-1.2 \mathrm{~K}$ ); and 2) a fish solubles and molasses blend ("fish"; 4N-0P-1.7K). Fertilizers were applied by fertigation through the drip system at rates of $56 \mathrm{~kg} \cdot \mathrm{ha}^{-1}$ nitrogen (N) per year in 2011-12 and $90 \mathrm{~kg} \cdot \mathrm{ha}^{-1} \mathrm{~N}$ in 2013 . The impact of fertigation on drip system performance was evaluated with two maintenance options, "flushing" and "no flushing" of the driplines. Total yield differed among years, whereas fruit soluble solids concentration and firmness as well as floricane biomass at pruning showed a year $x$ cultivar interaction. 'Black Diamond' had greater total yield and average fruit weight than 'Marion', but produced a greater proportion unmarketable fruit. There was no effect of fertilizer source on yield, fruit quality, primocane length, or primocanes/ plant in any year with the exception of fruit weight, which was greater with corn than with fish. 'Marion' had a greater floricane biomass when fertilized with fish than with corn. Soil nutrients were within the recommended range, except for boron (B), which was below recommended levels. Only soil nitrate- $\mathrm{N}$ was affected by fertilizer source, which was greater in 'Marion' than in 'Black Diamond' when fertilized with fish. Primocane leaf tissue nutrient concentrations were within recommended levels for all nutrients, except for calcium (Ca) and $B$, which were below recommended standards in both cultivars. Primocane leaf potassium $(\mathrm{K})$ and zinc $(\mathrm{Zn})$ concentrations were greater with fish than with corn. There was no fertilizer source or maintenance effect on emitter flow rate of the drip system in either year. However, flow rates decreased an average of $4.5 \%$ in the first year and $19 \%$ in the second year. Overall, there were no differences between the fertilizers on plant growth, yield, or fruit quality, and both fertilizers were suitable for planting establishment.
\end{abstract}

Fertilizer practices in blackberry (Rubus L. subgenus Rubus Watson) are routinely adjusted based on leaf tissue analysis (Hart et al., 2006). $\mathrm{N}$ is the predominant nutrient

Received for publication 19 Sept. 2014. Accepted for publication 18 Nov. 2014

We appreciate research funding support provided by the Northwest Center for Small Fruits Research, the USDA National Institute of Food and Agriculture (Formula Grant no. OREI 2010-01940; ORE00409), our industry contributors and collaborators, and the assistance provided by Gil Buller, Amanda Vance, and Emily Vollmer.

${ }^{1}$ From the MS thesis of J. Fernandez-Salvador.

${ }^{2}$ Professor.

${ }^{3}$ To whom reprint requests should be addressed; e-mail bernadine.strik@oregonstate.edu. applied to trailing blackberry, and the best growth and yield are usually achieved with $\approx 28$ to $56 \mathrm{~kg} \cdot \mathrm{ha}^{-1} \mathrm{~N}$ during the establishment year and $\approx 45$ to $84 \mathrm{~kg} \cdot \mathrm{ha}^{-1} \mathrm{~N}$ during the subsequent years in conventional and organic systems (Bushway et al., 2008; Hart et al., 2006; Kuepper et al., 2003). The most common $\mathrm{N}$ fertilizers applied to blackberry are calcium nitrate, urea, and ammonium sulfate in conventional systems and OMRI-listed (Organic Materials Review Institute) fish emulsion, pelletized chicken litter, soybean meal, or feather meal in organic systems (Fernandez-Salvador, 2014; Harkins et al., 2013). In blackberry, $\mathrm{N}$ must be available in early spring for sufficient primocane growth (Malik et al., 1991; Mohadjer et al., 2001; Naraguma and Clark, 1998). The current recommendation is to divide the total recommended rate of $\mathrm{N}$ into equal, "split" applications, generally from April to June in the northern hemisphere (Hart et al., 2006). Fertilizing through the irrigation system (fertigation) is an important tool because it targets the planting row directly and maximizes water and nutrient uptake while minimizing leaching of important nutrients (Gärdenäs et al., 2005). Organic blackberry has been established successfully when fertigating using fish emulsion from spring to midsummer (Harkins et al., 2013).

Blackberry plant nutrient status and fruit quality were affected by $\mathrm{N}$ fertilization when using granular, inorganic sources of $\mathrm{N}$ (Archbold et al., 1989; Naraguma and Clark, 1998; Nelson and Martin, 1986). In 'Arapaho', fertilizer $\mathrm{N}$ rate had little effect on yield, berry weight, or primocane number, but leaf $\mathrm{N}, \mathrm{P}, \mathrm{K}, \mathrm{Ca}$, sulfur (S), and manganese (Mn) levels were influenced by $\mathrm{N}$ application rate and timing (Naraguma and Clark, 1998). Spiers and Braswell (2002) found that varying rates of $\mathrm{N}, \mathrm{P}, \mathrm{K}$ and magnesium $(\mathrm{Mg})$ influenced leaf macronutrient concentration, where an increased rate of $\mathrm{N}$ led to higher leaf $\mathrm{N}$ and $\mathrm{P}$ and reduced leaf $\mathrm{K}$ and $\mathrm{Mg}$. In red raspberry (Rubus idaeus L.), applications of fertilizer $\mathrm{N}$ increased leaf $\mathrm{N}$ and fruit size but had no effect on yield (Chaplin and Martin, 1980). In organic production, FernandezSalvador et al. (2015) found relatively little effect of fertilizer source on yield and quality of hand-harvested blackberry when the fertilizer was applied to the in-row area. Little is known, however, about the influence of fertilizer sources of $\mathrm{N}$ that can be injected and fertigated on fruit yield and quality in organic blackberry.

In organic production systems, many factors must be taken into account in nutrient management programs, including availability and release rate of $\mathrm{N}$ from the fertilizer, ease of application, and cost. In addition, many nutrients other than $\mathrm{N}$ are present in organic fertilizers and are thus applied to the planting whether required or not (Harkins et al., 2014; Larco et al., 2013). Common organic sources of $\mathrm{N}$ range from cover crops to green manure for on-farm sources and fish byproducts, vegetable hydrolysate (e.g., corn steep liquor), molasses, animal manures (or manure-derived products), plant and animal byproducts (e.g. plant-based meals such as soybean meal and animal-based meals such as feather, bone, and meat), or mineralized materials (e.g., sodium nitrate or bat and bird guano) for off-farm sources (Gaskell and Smith, 2007; Kuepper, 2003; Mikkelsen and Hartz, 2008; OMRI, 2013; Sideman, 2007). Manure, for example, is a relatively inexpensive and abundant source of N; however, the U.S. Department of Agriculture (USDA) organic regulations only permit manure use with a restriction on preharvest interval (90 d for blackberry; OMRI, 2013). USDA National Organic-Program (NOP) compliant, OMRI-listed liquid fertilizer sources are limited and are believed to clog emitters, reducing fertilizer and water application efficiency (Schwankl and McGourty, 1992). 
Liquid fertilizer sources allowed in organic production include fish emulsions and hydrolysates, microbial digestions of vegetable byproducts (e.g., corn steep liquor), molasses, soy-derived amino acids, manure slurries and soluble guanos, and, in some cases, soluble mined minerals such as sodium nitrate and combinations of all of these (OMRI, 2013). Corn steep liquor has been studied as a $\mathrm{N}$ source in fertigation studies in tomato (Solanum lycopersicum L.) and muskmelon (Cucumis melo L.) (Nakano et al., 2001, 2003; Nakano and Uehara, 2003), whereas fish emulsion has widely been studied in various vegetables and fruits (Fernandez-Salvador, 2014; Fonte et al., 2009; Harkins et al., 2013; Larco et al., 2013; Strik et al., 2012; Young et al., 2005; Zhao et al., 2007). Corn steep liquor uses a high-volume byproduct of the corn syrup and starch industries and has been reviewed by the U.S. National Organic Standards Board (NOSB) for its compliance and use in organic production (NOSB Crops Committee, 2011). Corn steep liquor is comprised of the solubilized protein components of the corn endosperm and is relatively high in $\mathrm{N}$ and other minerals necessary for adequate plant growth (Keller and Heckman, 2006). Fish emulsion is also a readily available $\mathrm{N}$ source and is a byproduct of the fishing industry, primarily in Alaska and Mexico (OMRI, 2013). For example, over 1,000,000 t of fish waste is produced in Alaska every year and used for fertilizer or animal feed (Zhang et al., 2007). Schwankl and McGourty (1992) found that spray-dried fish protein and poultry protein performed well in fertigation systems with minimal clogging. Corn steep liquor has not been specifically studied for its performance in drip fertigation systems; however, it is known to be soluble in water (Keller and Heckman, 2006). Corn steep liquor and fish emulsion fertilizers are valued in organic agriculture as rapid-release $\mathrm{N}$ sources with no required preharvest application period restriction, which is mandatory for uncomposted or unprocessed animal manures under the USDA NOP.

Management of fertigation through the drip system is important. Less optimal fertigation management can lead to uneven distribution of nutrients and water, a reduction in the lifespan of a fertigation system and/or increase in maintenance costs, a reduction in nutrient availability, and may reduce yield (Hanson et al., 2006). It is thus important for organic growers to have information regarding fertilizer options suited for use in fertigation systems.

The objectives of this study were to 1) determine the impact of two organically approved liquid fertilizer sources applied through fertigation on plant growth, yield, fruit quality, and soil and plant tissue nutrient status of 'Marion' and 'Black Diamond' blackberry grown in an organic production system; and 2) assess the impact of fertilizer source on the performance of the drip irrigation/fertigation system. 'Marion' and 'Black Diamond' are predominantly harvested by machine for high-value processed markets and together accounted for greater than $75 \%$ of the 2914 ha of blackberries produced in Oregon in 2012 (National Agricultural Statistical Service, 2013). Like all trailing types, the plant crowns and roots are perennial, but the shoots are biennial, producing primocanes the first year, which then become floricanes with flowers and fruit the next year and senesce after harvest. Mature plants will have both primocanes and floricanes in the same year in a typical annual or every-year production system (Julian et al., 2009; Strik and Finn, 2012).

\section{Materials and Methods}

Study site. The study was conducted at the North Willamette Research and Extension Center in Aurora, OR [lat. $45^{\circ} 17^{\prime} \mathrm{N}$, long. $122^{\circ} 45^{\prime} \mathrm{W}$; elevation $46 \mathrm{~m}$; USDA hardiness zone 8b (2012); elevation $46 \mathrm{~m}]$. Soil at the site is a Willamette silt loam (fine-silty, mixed, superactive mesic Pachic Ultic Argixeroll) that had a $\mathrm{pH}$ of 5.3 before planting and contained $3.6 \%$ organic matter, $1.5 \mathrm{ppm} \mathrm{NO}_{3}-\mathrm{N}, 2.3 \mathrm{ppm}$ $\mathrm{NH}_{4}-\mathrm{N}, 188$ ppm P (Bray I), and 295 ppm K. Soil $\mathrm{pH}$ and $\mathrm{K}$ were low and below the ranges recommended for the crop (i.e., $\mathrm{pH} 5.6$ to 6.5 and soil $\mathrm{K}$ greater than $350 \mathrm{ppm}$; Hart et al., 2006) and therefore, based on McLean (1982), lime [calcium carbonate $\left(2242 \mathrm{~kg} \cdot \mathrm{ha}^{-1}\right)$ and dolomite $\left(4148 \mathrm{~kg} \cdot \mathrm{ha}^{-1}\right)$ ] and K-Mag fertilizer $\left(102 \mathrm{~kg} \cdot \mathrm{ha}^{-1} \mathrm{~K}, 62 \mathrm{~kg} \cdot \mathrm{ha}^{-1} \mathrm{Mg}, 102 \mathrm{~kg} \cdot \mathrm{ha}^{-1} \mathrm{~S}\right)+$ micronutrients $\left[2 \mathrm{~kg} \cdot \mathrm{ha}^{-1} \mathrm{~B}\left(\mathrm{H}_{3} \mathrm{BO}_{3}\right), 1 \mathrm{~kg} \cdot \mathrm{ha}^{-1}\right.$ copper $(\mathrm{Cu})\left(\mathrm{CuSO}_{4}\right)$, and $14 \mathrm{~kg} \cdot \mathrm{ha}^{-1}$ $\left.\mathrm{Zn}\left(\mathrm{ZnSO}_{4}\right)\right]$ were broadcast and incorporated into each row before planting. See Harkins et al. (2013) for further information on site preparation.

The field was planted with tissue-cultured plugs on 26 May 2010. Weeds were managed using a 1.4-m-wide strip of black, woven polyethylene groundcover ("weed mat"; water flow rate $6.8 \mathrm{~L} \cdot \mathrm{h} \cdot \mathrm{m}^{-2}$; density $0.11 \mathrm{~kg} \cdot \mathrm{m}^{-2}$; TenCate Protective Fabrics; OBC Northwest, Inc., Canby, OR) centered on the row. Irrigation was applied using a single lateral of drip tubing (UNIRAM; Netafim USA, Fresno, CA) installed in each treatment plot immediately after planting. The tubing had $1.9 \mathrm{~L} \cdot \mathrm{h}^{-1}$ in-line, pressure-compensating emitters spaced every $0.6 \mathrm{~m}$ and was placed under the weed mat, at the base of the plants. Irrigation was scheduled weekly based on estimates of crop evapotranspiration and measurements of primocane leaf water potential and soil water content as described by Harkins et al. (2013). The site was first certified organic by a USDA-accredited agency (Oregon Tilth Certified Organic, Corvallis, OR) in May 2012. Although approved practices were conducted during the 3 years before planting and in the establishment year, organic certification was not obtained until the first fruit harvest year.

Primocane training. Annual development of typical blackberry plantings in the Pacific Northwest is described by Harkins et al. (2013). Plants were trained on a three-wire vertical trellis system in each row that was installed before planting. The lower trellis wire was attached to steel posts at $0.3 \mathrm{~m}$ above the ground, the middle wire at $1.0 \mathrm{~m}$, and the upper wire was attached at $1.6 \mathrm{~m}$. Primocanes that grew in Year 1 (2010, the planting year) were removed the next winter (Feb. 2011) to increase subsequent growth and promote plant establishment, as per standard commercial practice (Strik and Finn, 2012). In Year 2 (2011), primocanes were trained to the trellis wires as they grew using twine. Once the primocanes grew above the upper trellis wire, half the canes were looped in one direction down to the lower trellis wire and brought back toward the plant with one or two twists, and the other half was looped in the opposite direction. By Years 3 (2012) and 4 (2013), plants had primocanes and floricanes (the previous year's primocanes). At this point, new primocanes were bundled and tied to the bottom wire below the floricane canopy to avoid cane damage and were trained to the trellis in late August, after the senescing floricanes were removed by pruning.

Experimental design. The study was conducted from 2011 to 2013 and included the first and second fruiting seasons, Years 3 and 4 , respectively. Treatments were arranged as a randomized block design with five replicates and included cultivar (Marion and Black Diamond) and fertilizer source [corn steep liquor and fish waste digestion blend ("corn"; $2.5 \mathrm{~N}-1.1 \mathrm{P}-1.2 \mathrm{~K}$ ) and fish solubles and molasses blend ("fish"; $4 \mathrm{~N}-0 \mathrm{P}-1.7 \mathrm{~K}$ )]. Each plot consisted of four plants spaced $1.5 \mathrm{~m}$ apart in-row and was separated from plants in adjacent plots by $3.0 \mathrm{~m}$ of unplanted space covered with weed mat (to provide space for clearing the machine harvester). Between-row spacing was $3.0 \mathrm{~m} \mathrm{(2222}$ plants/ha). The impact of fertigation on drip system performance was evaluated using a split-plot design with two maintenance options, "flushing" and "no flushing" of the driplines, as the main plot and the two fertilizer sources (corn and fish) as the subplots with three replicates.

Fertilizer applications. Before planting in Year 1, pelletized, processed poultry litter (4N-1.3P-1.7K-7Ca; Nutri-Rich; Stutzman Environmental Products Inc., Canby, OR) was incorporated into the soil $(\approx 0.45 \mathrm{~m}$ diameter $)$ at a rate of $28 \mathrm{~kg} \cdot \mathrm{ha}^{-1}$ of $\mathrm{N}$. In addition, Fish Agra (4N-0.4P-0.8K; Northeast Organics, Manchester-by-the-Sea, MA) was diluted with 10 parts water $(\mathrm{v} / \mathrm{v})$ and applied by hand, around the base of plants, in seven weekly applications of $4 \mathrm{~kg} \cdot \mathrm{ha}^{-1} \mathrm{~N}$ each from 14 July to 25 Aug. 2010 ( $28 \mathrm{~kg} \cdot \mathrm{ha}^{-1}$ total N).

The two fertilizer source treatments were applied at an equivalent rate of $\mathrm{N}\left(56 \mathrm{~kg} \cdot \mathrm{ha}^{-1}\right.$ in 2011-12 and $90 \mathrm{~kg} \cdot \mathrm{ha}^{-1}$ in 2013) based on the percent total $\mathrm{N}$ in the product as stated on the label. The fish fertilizer used was a fish hydrolysate and fish emulsion blend combined with molasses (TRUE 402; 4N-0P-1.7K; True Organic Products, Inc., Spreckels, CA) that was diluted with five parts water $(\mathrm{v} / \mathrm{v})$ before injection through the drip system (fertigation). The corn fertilizer used was a natural microbial digestion of corn steep liquor and ground fish waste (AgroThrive $2.5 \mathrm{~N}-1.1 \mathrm{P}-1.2 \mathrm{~K}$ ) 
produced by a Progressive Digestion Process (PDP, patent pending by the manufacturer, AgroThrive, Inc., Morgan Hill, CA) and stabilized by thermophilic fermentation; the corn fertilizer was diluted with two parts water $(\mathrm{v} / \mathrm{v})$ before fertigation. The fertilizers were injected through the drip irrigation system using a combination of a water-driven pump fertilizer injector (Mix-Rite $571 \mathrm{CW}$; DEMA, St. Louis, MO) and an electric, low-volume chemigation pump system (Insectigator III; Agri-Inject, Inc., Yuma, CO) to reduce injection time. The dilution rate differed for the products studied as a result of differences in product viscosity or density; dilution rates were chosen such that the fertilizer injector used delivered the same rate of fertilizer $\mathrm{N}$ per unit of time for each product. Irrigation was run for $10 \mathrm{~min}$ before each injection to fully pressurize the system to $103.4 \mathrm{kPa}$ and was also run for an additional $4 \mathrm{~h}$ after injection to flush the driplines. In 2011 and 2012, the fish was fertigated in equal portions on 18 Apr., 13 May, and 3 and 24 June 2011 and 25 Apr., 11 May, and 1 and 15 June 2012 (56 kg.ha ${ }^{-1}$ total N). In 2013, the fish was fertigated in equal portions on 10 and 17 Apr., 1, 15, and 30 May, 13 and 27 June, and 11 July $\left(90 \mathrm{~kg} \cdot \mathrm{ha}^{-1}\right.$ total $\left.\mathrm{N}\right)$. The corn fertilizer was fertigated in four equal portions on 22 Apr., 17 May, and 7 and 24 June 2011 and 27 Apr., 15 May, and 4 and 18 June 2012 $\left(56 \mathrm{~kg} \cdot \mathrm{ha}^{-1}\right.$ total $\left.\mathrm{N}\right)$ and in eight equal portions on 12 and 20 Apr., 8 and 23 May, 6 and 20 June, and 2 and 17 July 2013 (90 kg.ha ${ }^{-1}$ total N). Nitrogen rate was increased in 2013 based on leaf tissue testing the prior year (Hart et al., 2006).

The fertilizers studied were analyzed for total nutrient content (Brookside Laboratories, New Bremen, $\mathrm{OH}$ ), and the rate of all macroand micronutrients applied was calculated. Additionally, $2.2 \mathrm{~kg} \cdot \mathrm{ha}^{-1}$ of B (Solubor; 20 Mule Team Borax, Englewood, CO) were applied on $28 \mathrm{Feb} .2013$, and $560 \mathrm{~kg} \cdot \mathrm{ha}^{-1}$ of pelletized dolomitic lime $\left[62 \mathrm{~kg} \cdot \mathrm{ha}^{-1} \mathrm{Mg}\right.$ and $112 \mathrm{~kg} \cdot \mathrm{ha}^{-1} \mathrm{Ca}$ (Pro-Pell_it! Pelletized Dolomite; Marion Ag Service, Inc., St. Paul, OR)] and $2242 \mathrm{~kg} \cdot \mathrm{ha}^{-1}$ of pelletized lime (Pro-Pell_it! Pelletized Lime; Marion Ag Service, Inc.) were applied as a broadcast to the plots and aisles on 8 Mar. 2013. Groundcovers, as used in our study, have been shown to allow for fertilizers applied on top to penetrate the woven material and become available to the plants (Zibilske, 2010).

Plant growth and fruit production. Primocanes (at $0.3 \mathrm{~m}$ height) were counted on two separate plants in each four-plant plot in Mar. 2012, Feb. 2013, and Mar. 2014 to assess treatment effects on primocane number in 2011-13, respectively (per Harkins et al., 2013). In Mar. 2012, a primocane from each of two separate plants in each four plant plot was randomly selected and measured for cane length, weighed, and oven-dried at $70{ }^{\circ} \mathrm{C}$ before being reweighed and calculating average percent primocane dry weight (DW) and total primocane DW/plant.

Ripe fruit were harvested twice weekly from 5 July to 30 July in 2012 and from 24
June to 19 July in 2013 using an over-the-row rotary harvester (Littau Harvesters Inc., Stayton, OR). Total marketable and unmarketable fruit ("culls," including overripe, dropped, sunburned, damaged, rotten, or underripe fruit) were weighed on each harvest date and total yield calculated. A sample of 25 berries was hand-picked just before each machine harvest date, randomly selecting fruit from both sides of the row and covering the entire length of the plot area. The subsample was used to determine average fruit quality variables, including: fruit weight (seasonal, weighted average calculated), fruit firmness, and percent soluble solids ( ${ }^{\circ}$ Brix). Fruit firmness of each berry was measured using a University of California Manual Firmness Tester (Serial No. 364; Western Industrial Supply, San Francisco, CA) with a mechanical force gauge (Ametek Model LKG1, Feasterville, PA). Each berry was laid on its side and force was applied until the first drop of juice came out of one or more drupelets. The fruit were then placed in a 1-L polyethylene resealable bag and crushed by hand to obtain a homogeneous mixture for measuring percent soluble solids on a temperature-compensated digital refractometer (Atago, Bellevue, WA).

Senescing floricanes were removed by pruning at the base of the plant $(\approx 0.1 \mathrm{~m}$ high) after fruit harvest on 6 Aug. 2012 and 15 Aug. 2013 per standard commercial practice (Strik and Finn, 2012). The total fresh biomass of the pruned floricanes was determined per plot. In 2012 and 2013, one floricane was randomly sampled from each of two plants per plot, weighed, oven-dried at $70{ }^{\circ} \mathrm{C}$, reweighed, and average floricane fresh and DW calculated (as per Harkins et al., 2013). Total floricane DW/plot and DW/plant were estimated based on the number of floricanes/plot and plants/plot, respectively. Additionally in 2013, each sampled floricane was measured for length and the total number of nodes, fruiting laterals, and fruiting sites per cane were counted. The remaining floricane prunings were placed between rows and flail-mowed (chopped) as per standard commercial practice. Once the senescent floricanes were removed, the new primocanes were trained to the trellis as previously described.

Tissue and soil analysis. Tissue samples were collected from the primocane leaves on 17 Aug. 2012 and 16 Aug. 2013 per standard recommendations (Hart et al., 2006). Samples consisted of 10 recent fully expanded leaves selected from both sides of the row on each plot and were sent to Brookside Laboratories. Total $\mathrm{N}$ content was determined in each sample using a combustion analyzer, and $\mathrm{P}, \mathrm{K}, \mathrm{Ca}, \mathrm{Mg}, \mathrm{S}$, iron ( $\mathrm{Fe}), \mathrm{B}, \mathrm{Cu}, \mathrm{Mn}, \mathrm{Zn}$, and aluminum were determined using an inductively-coupled plasma (ICP) spectrophotometer after wet washing the samples in nitric/perchloric acid (Gavlak et al., 1994). Nutrient concentrations in the primocane leaves were compared with published standards (Hart et al., 2006).

Soil samples were collected on 2 Nov. 2012 and 23 Oct. 2013 using a 2.4-cm diameter, 0.5-m long, slotted, open-side, chrome-plated steel soil probe (Soil Sampler Model Hoffer; JBK Manufacturing, Dayton, OH). One sample was collected per treatment plot with each sample composed of four cores collected to a depth of $0.3 \mathrm{~m}$ at the center of the row in between the two middle plants; all cores were within the water emitter drip zone of the in-row area. The cores were combined in a bucket and a subsample sent for analysis to Brookside Laboratories and extractable soil $\mathrm{P}$ (Bray I), K, Ca, $\mathrm{Mg}$, sulphate-sulfur $\left(\mathrm{SO}_{4}-\mathrm{S}\right)$, sodium $(\mathrm{Na}), \mathrm{B}, \mathrm{Cu}, \mathrm{Mn}$, and $\mathrm{Zn}$ were determined by ICP after extraction of the nutrients using the Mehlich 3 method (Mehlich, 1984). Soil nitrate-nitrogen $\left(\mathrm{NO}_{3}-\mathrm{N}\right)$ and ammonium-nitrogen $\left(\mathrm{NH}_{4}-\mathrm{N}\right)$ were determined using automated colorimetric methods after extraction with $1 \mathrm{M} \mathrm{KCl}$ (Dahnke, 1990). Soil organic matter was measured using Loss-On-Ignition at $360{ }^{\circ} \mathrm{C}$ (Nelson and Sommers, 1996) and soil $\mathrm{pH}$ using the 1:1 soil:water method (McLean, 1982).

Fertigation and drip system performance. Water volume from the emitters was measured in plots with the "flush" treatment after opening the valve at the end of the dripline, flushing with irrigation water for $1 \mathrm{~min}$, and then reclosing the valve. In the "no flush" treatment plots, the flushing valve at the end of the dripline remained closed during the study. To evaluate emitter flow, $\approx 5 \mathrm{~m}$ of each treatment plot's dripline was raised onto metallic stakes of $\approx 0.3 \mathrm{~m}$ height until each of six emitters was dripping directly into 0.25 -L beakers. Water volume from the emitters was measured after 5 min using graduated cylinders. Flow measurements were taken on three occasions in each year: during or after the fertigation season was completed (7 May 2012, 29 July 2013), during or after harvest (25 July 2012, 9 Aug. 2013), and after the floricanes were removed by pruning (13 Sept. 2012, 12 Sept. 2013). The average volume per plot was calculated for all 2012 and 2013 measurements.

Data analyses. Data were analyzed for a split-plot design with year as the main plot factor and cultivar and fertilizer as subplots using the General Linear Model procedure in SAS (Version 9.3; SAS Institute Inc., Cary, NC). Residuals were tested for normality using the Shapiro-Wilk test and data were log-transformed and analyzed where necessary to meet criteria for normality and homogeneity of variance. Means were compared for treatment effects using a Fisher's protected least significant difference with $\alpha=0.05$. Mean comparisons within significant interactions were done for treatments using least square means with $\alpha=0.05$. The drip water flow data were analyzed for a split-plot design using year as the main plot factor and fertilizer and maintenance of the drip system as subplots using the same statistical procedures as previously described.

\section{Results and Discussion}

Fertilizer source. The fertilizer applied in 2011 came from different batches than that 
applied in 2012 and 2013. Although the rate of product applied for each fertilizer was calculated based on the percentage of $\mathrm{N}$, as stated on the label for a target rate of $\mathrm{N}$ $\left(56 \mathrm{~kg} \cdot \mathrm{ha}^{-1}\right.$ total $\mathrm{N}$ in 2011 and 2012 and $90 \mathrm{~kg} \cdot \mathrm{ha}^{-1}$ in 2013), the actual rate of $\mathrm{N}$ applied was $50 \mathrm{~kg} \cdot \mathrm{ha}^{-1}$ and $62 \mathrm{~kg} \cdot \mathrm{ha}^{-1}$ in 2011-12 and 80 and $99 \mathrm{~kg} \cdot \mathrm{ha}^{-1}$ in 2013 for the fish and corn products, respectively (Table 1). Thus, $\approx 24 \%$ more total fertilizer $\mathrm{N}$ was unintentionally applied when plants were fertilized with corn than with fish as the source. In addition, the corn fertilizer contained more than 3-fold the $\mathrm{P}$ and $\mathrm{Ca}, 8$-fold the $\mathrm{Mg}$, and 2-fold the $\mathrm{B}, \mathrm{Mn}, \mathrm{Cu}$, and $\mathrm{Zn}$ than the fish fertilizer, whereas the fish fertilizer contained more than 22-fold the $\mathrm{Na}$ and more than 7-fold the Fe than the corn fertilizer (Table 1). The $\mathrm{N}$ content of corn steep liquor may vary with levels as high as $7.5 \%$, and it is considered a relatively complete fertilizer source (Keller and Heckman, 2006).

Plant growth and yield. Cultivar and fertilizer source had no significant effect on primocane length or biomass in 2011, the "off year" (primocanes growing without the presence of floricanes), but there was a significant effect of cultivar $(P=0.0004)$ on primocane number per plant. 'Black Diamond' produced more primocanes in 2011 (12.9 canes/plant) than 'Marion' (9.0 canes/ plant; Fernandez-Salvador, 2014). In 2012 and 2013 (years with primocanes and floricanes growing simultaneously), there were inconsistent treatment effects on primocane growth. There was no fertilizer or cultivar effect on primocane number in 2012 (averaging 3.3 primocanes/plant), but 'Marion' produced longer canes $(7.6 \mathrm{~m})$ than 'Black Diamond' (4.9 m) $(P=0.0463)$. In 2013, 'Black Diamond' produced more primocanes (9.8 canes/plant) than 'Marion' (6.6 canes/plant) $(P<.0001 ;$ Fernandez-Salvador, 2014). Our results showing 'Black Diamond' produced more canes/plant but shorter canes than 'Marion' agree with those of Harkins et al. (2013). Primocane growth was likely reduced in 2012 as a result of the high yield in this first fruiting season (Table 2), as is typical after an off year (Strik and Finn, 2012). The presence of floricanes has been shown to reduce primocane number and length (Bell et al., 1995; Cortell and Strik, 1997). Under conditions of limited available $\mathrm{N}$, as may occur under a high floricane sink strength, primocane growth may be reduced (Malik et al., 1991; Mohadjer et al., 2001). In 2013, the observed increase in primocane number may have been a result of the increased rate of $\mathrm{N}$ applied (Table 1) and/or the reduced sink strength of the floricanes because yield was lower in 2013 than in 2012 (Table 2).

Machine harvest of 'Black Diamond' began $5 \mathrm{~d}$ earlier and lasted $5 \mathrm{~d}$ longer than 'Marion' in both years and the 2013 harvest season was $12 \mathrm{~d}$ earlier than in 2012 for both cultivars (data not shown). Total yield was affected by year and cultivar but not fertilizer source in the two fruiting seasons of the study (Table 2). Total yield was $29 \%$ greater in

Table 1. Total nutrients applied in organic fertilizer treatments in blackberry grown at the North Willamette Research and Extension Center, Aurora, OR, 2011-12 and 2013. ${ }^{\mathrm{z}}$

\begin{tabular}{|c|c|c|c|c|c|c|c|c|c|c|c|c|}
\hline \multirow[b]{2}{*}{ Fertilizer $^{2}$} & \multirow{2}{*}{$\begin{array}{c}\text { Treatment } \\
\text { name }\end{array}$} & \multicolumn{6}{|c|}{ Macronutrients $\left(\mathrm{kg} \cdot \mathrm{ha}^{-1}\right)$} & \multicolumn{5}{|c|}{ Micronutrients $\left(\mathrm{g} \cdot \mathrm{ha}^{-1}\right)$} \\
\hline & & $\mathrm{N}$ & $\mathrm{P}$ & $\mathrm{K}$ & $\mathrm{Ca}$ & $\mathrm{Mg}$ & $\mathrm{Na}$ & $\mathrm{B}$ & $\mathrm{Fe}$ & $\mathrm{Mn}$ & $\mathrm{Cu}$ & $\mathrm{Zn}$ \\
\hline & & & & & $\overline{011-}$ & & & & & & & \\
\hline TRUE 402 & Fish & 50 & 8 & 60 & 1 & 1 & 27 & 12 & 307 & 19 & 4 & 48 \\
\hline Agrothrive LF & Corn & 62 & 30 & 40 & 3 & 8 & 1 & 23 & 40 & 49 & 9 & 97 \\
\hline & & & & & 201 & & & & & & & \\
\hline TRUE 402 & Fish & 80 & 14 & 98 & 1 & 1 & 44 & 20 & 496 & 30 & 6 & 77 \\
\hline Agrothrive LF & Corn & 99 & 47 & 63 & 4 & 13 & 2 & 37 & 63 & 78 & 15 & 154 \\
\hline
\end{tabular}

${ }^{\mathrm{z}}$ Fertilizers were analyzed by Brookside Laboratories, Inc. (New Bremen, OH). The fish hydrolysate and fish emulsion blend combined with molasses fertilizer was diluted with water $(1: 5, \mathrm{v} / \mathrm{v})$ before injection in four equal portions in Spring 2011 and 2012 and eight equal portions in Spring 2013. The corn steep liquor and ground fish waste fertilizer were diluted with water $(1: 2, \mathrm{v} / \mathrm{v})$ before injection in four equal portions in Spring 2011 and 2012 and eight equal portions in Spring 2013. TRUE $4024 \mathrm{~N}-0 \mathrm{P}-1.7 \mathrm{~K}$ had a pH of 5.5 and Agrothrive LF $2.5 \mathrm{~N}-1.1 \mathrm{P}-1.2 \mathrm{~K}$ had a $\mathrm{pH}$ of 3.98 .

Table 2. Effect of cultivar and fertilizer source on total and marketable fruit yield, fruit weight, percent soluble solids $\left({ }^{\circ} \mathrm{Brix}\right)$, and fruit firmness in machine-picked organic blackberry grown at the North Willamette Research and Extension Center, Aurora, OR, 2012-13 ( $\mathrm{n}=5)$.

\begin{tabular}{|c|c|c|c|c|c|c|c|}
\hline Treatments & $\begin{array}{l}\text { Total yield } \\
\text { (kg/plant) }\end{array}$ & $\begin{array}{c}\text { Marketable } \\
\text { yield ( } \mathrm{kg} / \text { plant })\end{array}$ & $\begin{array}{l}\text { Fruit } \\
\text { wt (g) }\end{array}$ & \multicolumn{2}{|c|}{ Soluble solids (\%) } & \multicolumn{2}{|c|}{ Fruit firmness $(\mathrm{N})$} \\
\hline \multicolumn{8}{|l|}{ Year } \\
\hline 2012 & $7.1 \mathrm{a}^{\mathrm{z}}$ & 6.3 & 5.9 & & \multicolumn{2}{|c|}{2.1} \\
\hline 2013 & $5.5 \mathrm{~b}$ & 4.4 & 5.8 & & 11.4 & \multicolumn{2}{|c|}{2.0} \\
\hline Cultivar & & & & 2012 & 2013 & 2012 & 2013 \\
\hline Black Diamond & $7.0 \mathrm{a}$ & $5.8 \mathrm{a}$ & $6.0 \mathrm{a}$ & $10.3 \mathrm{~b}$ & $9.8 \mathrm{c}$ & $2.5 \mathrm{a}$ & $2.2 \mathrm{~b}$ \\
\hline Marion & $5.6 \mathrm{~b}$ & $4.8 \mathrm{~b}$ & $5.6 \mathrm{~b}$ & $12.9 \mathrm{a}$ & $13.0 \mathrm{a}$ & $1.6 \mathrm{c}$ & $1.7 \mathrm{c}$ \\
\hline \multicolumn{8}{|l|}{ Fertilizer $^{\mathrm{y}}$} \\
\hline Fish & 6.3 & 5.4 & $5.7 \mathrm{~b}$ & \multirow{2}{*}{\multicolumn{2}{|c|}{11.5}} & \multicolumn{2}{|c|}{2.0} \\
\hline Corn & 6.2 & 5.3 & $6.0 \mathrm{a}$ & & & & \\
\hline \multicolumn{8}{|l|}{ Significance $^{x}$} \\
\hline Year (Y) & 0.0484 & NS & NS & \multicolumn{2}{|c|}{ NS } & \multicolumn{2}{|c|}{ NS } \\
\hline Cultivar (C) & $<0.0001$ & 0.0006 & 0.0063 & \multicolumn{2}{|c|}{$<0.0001$} & \multicolumn{2}{|c|}{$<0.0001$} \\
\hline Fertilizer $(\mathrm{F})$ & NS & NS & 0.0470 & \multirow{2}{*}{\multicolumn{2}{|c|}{$\begin{array}{l}\text { NS } \\
<0.0001\end{array}$}} & \multirow{2}{*}{\multicolumn{2}{|c|}{$\begin{array}{c}\text { NS } \\
<0.0001\end{array}$}} \\
\hline $\mathrm{Y} \times \mathrm{C}$ & NS & NS & NS & & & & \\
\hline $\mathrm{C} \times \mathrm{F}$ & NS & NS & NS & \multirow{2}{*}{\multicolumn{2}{|c|}{ NS }} & \multicolumn{2}{|c|}{ NS } \\
\hline $\mathrm{Y} \times \mathrm{C} \times \mathrm{F}$ & NS & NS & NS & & & \multicolumn{2}{|c|}{ NS } \\
\hline
\end{tabular}

${ }^{2}$ Means followed by the same letter within the treatment or interaction are not significantly different $(P>0.05)$.

${ }^{y}$ Fertilizer products used were: a blend of fish hydrolysate and fish emulsion combined with molasses ("fish," TRUE 402; 4N-0P-1.7K; True Organic Products, Inc., Spreckels, CA) and corn steep liquor ("corn," Agrothrive LF; 2.5N-1.1P-1.2K; Agrothrive Inc., Morgan Hill, CA). The two fertilizer source treatments were applied at an equivalent total rate of $\mathrm{N}\left(56 \mathrm{~kg} \cdot \mathrm{ha}^{-1}\right.$ in 2012 and $90 \mathrm{~kg} \cdot \mathrm{ha}^{-1}$ in 2013) based on the percent $\mathrm{N}$ in the product as stated on the label.

${ }^{\times} P$ value provided unless nonsignificant (Ns; $P>0.05$ ).

2012 than in 2013 (Table 2), as is typical when a fruiting season follows an "off year" or primocane-only growth year (Bell et al., 1995; Cortell and Strik, 1997; Strik and Finn, 2012). 'Black Diamond' had a $25 \%$ and $21 \%$ greater average total and marketable yield, respectively, than 'Marion'. The proportion of non-marketable fruit varied among cultivars in 2012 and 2013, averaging 17\% for 'Black Diamond' and 14\% for 'Marion (Fernandez-Salvador, 2014). Our findings disagree with those of Harkins et al. (2013), who reported that 'Marion' produced more cull fruit than 'Black Diamond'; however, the cull fruit in their study was limited to machine-sorted cull, whereas our cull included fruit dropped during machine harvest. 'Black Diamond' may have a lower machine harvest efficiency than 'Marion'. In a separate study, we found that 'Marion' also produced less cull fruit than 'Black Diamond' when hand-harvested (Fernandez-Salvador et al., 2015). The greater yield of 'Black Diamond' was likely a result of the cultivar having a higher percent budbreak and more fruit/lateral than found in 'Marion' (Table 3), as has been reported previously (Fernandez-Salvador et al., 2015; Harkins et al., 2013). 'Marion' floricanes were $3.8 \mathrm{~m}$ longer, on average, than in 'Black Diamond', but 'Marion' had a lower percent budbreak (Table 3). Although these might be cultivar differences, percent budbreak has been shown to increase with shorter canes (Bell et al., 1995).

Fruit weight was significantly affected by cultivar and fertilizer in both years (Table 2). Plants fertilized with corn produced 5\% heavier fruit than those fertilized with fish, on average. 'Black Diamond' produced 7\% larger fruit, on average, than 'Marion', as has been reported previously in organic blackberry production (Fernandez-Salvador et al., 2015; Harkins et al., 2013). Fruit weight 
declined over the harvest seasons in both cultivars (data not shown), as has been reported previously (Fernandez-Salvador et al., 2015). 'Marion' fruit had a higher percent soluble solids than found in 'Black Diamond', especially in 2013, as found by Harkins et al. (2013). However, Siriwoharn et al. (2004) reported a similar sucrose content of 'Black Diamond' and 'Marion' fruit. In our study, midseason fruit had a lower percent soluble solids than earlyor late-season fruit in both cultivars, particularly in 2013 (Fernandez-Salvador, 2014), as has been reported previously (Fernandez-Salvador et al., 2015). Fruit harvested in the early season were more firm than late-season fruit in both cultivars (data not shown). 'Black Diamond' fruit were more firm than 'Marion' fruit, particularly in 2012 (Table 2), similar to previous reports (Fernandez-Salvador et al., 2015; Finn et al., 2005). There was no effect of fertilizer source on the percent soluble solids or fruit firmness in either year.

There was a significant year $\times$ cultivar and cultivar $\times$ fertilizer interaction on floricane fresh biomass (data not shown) and DW/plant at pruning time (Table 4). 'Marion' produced $53 \%$ and $43 \%$ greater floricane DW biomass per plant than 'Black Diamond' in 2012 and 2013, respectively (Table 4). Additionally, 'Marion' had greater floricane DW biomass when fertilized with corn than with fish, whereas there was no effect of fertilizer source in 'Black Diamond' (Table 4). Greater canopy growth in 'Marion' compared with 'Black Diamond' was also reported by Harkins et al. $(2013,2014)$.

Soil and tissue nutrients. Soil $\mathrm{pH}$ was within the recommended range for blackberry production (5.6 to 6.5; Hart et al., 2006) (Table 5). The soil organic matter (OM) content was significantly higher in 2013 than in 2012, although OM was not added underneath the weed mat. The increase in OM was likely the result of the presence of fine blackberry roots in the soil sample, the presence of which likely increased during these establishment years. Most of the nutrient levels in the soil were within or above the recommended range for blackberry in Oregon (Hart et al., 2006). Soil P, K, Ca, and $\mathrm{Mg}$ were considerably above recommended levels (P-Bray, 20 to 40 ppm; K, 150 to $350 \mathrm{ppm}$; $\mathrm{Ca}, 1000 \mathrm{ppm}$; and $\mathrm{Mg}, 120 \mathrm{ppm}$; Hart et al., 2006) in both years (Table 6). Soil B was below the recommended level $(0.5$ to $1.0 \mathrm{ppm}$ ) in both years (Table 5).

The level of soil $\mathrm{P}$ decreased and $\mathrm{Ca}$ increased significantly from 2012 to 2013. The increase in Ca was likely the result of the application of lime the prior winter, and the decrease in $\mathrm{P}$ may have been a consequence of plant uptake from the previous year. There was no effect of cultivar on soil nutrient level, but there was a cultivar $\times$ fertilizer interaction on soil $\mathrm{NO}_{3}-\mathrm{N}$ (Table 5). Fertilization with fish increased soil $\mathrm{NO}_{3}-\mathrm{N}$ in 'Marion' plots relative to 'Black Diamond' plots, whereas there was no difference among cultivars when corn was the fertilizer source. Soil

Table 3. Effects of cultivar and fertilizer source on floricane traits (yield components) in organic blackberry grown at the North Willamette Research and Extension Center, Aurora, OR, in $2013(\mathrm{n}=5)$.

\begin{tabular}{|c|c|c|c|c|c|}
\hline Treatments & $\begin{array}{l}\text { Floricane } \\
\text { length }(\mathrm{m})\end{array}$ & $\begin{array}{l}\text { No. of } \\
\text { nodes }\end{array}$ & $\begin{array}{l}\text { Internode } \\
\text { length }(\mathrm{cm})\end{array}$ & $\begin{array}{c}\text { Budbreak } \\
(\%)\end{array}$ & Fruit/lateral \\
\hline \multicolumn{6}{|l|}{ Cultivar } \\
\hline Black Diamond & $4.8 \mathrm{~b}^{\mathrm{z}}$ & 116.4 & $4.2 \mathrm{~b}$ & $67.0 \mathrm{a}$ & $11.1 \mathrm{a}$ \\
\hline Marion & $8.6 \mathrm{a}$ & 117.1 & $7.3 \mathrm{a}$ & $53.0 \mathrm{~b}$ & $8.0 \mathrm{~b}$ \\
\hline \multicolumn{6}{|l|}{ Fertilizer $^{\mathrm{y}}$} \\
\hline Fish & 6.9 & 120.5 & 5.9 & 59.8 & 9.8 \\
\hline Corn & 6.5 & 113.1 & 5.7 & 60.2 & 9.3 \\
\hline \multicolumn{6}{|l|}{ Significance $^{\mathrm{x}}$} \\
\hline Cultivar (C) & $<0.0001$ & NS & $<0.0001$ & 0.0029 & $<0.0001$ \\
\hline Fertilizer $(\mathrm{F})$ & NS & NS & NS & NS & NS \\
\hline $\mathrm{C} \times \mathrm{F}$ & NS & NS & NS & NS & NS \\
\hline
\end{tabular}

${ }^{\mathrm{z}}$ Means followed by the same letter within the treatment or interaction are not significantly different $(P>0.05)$.

${ }^{y}$ Fertilizer products used were: a blend of fish hydrolysate and fish emulsion combined with molasses ("fish," TRUE 402; 4N-0P-1.7K; True Organic Products, Inc., Spreckels, CA) and corn steep liquor ("corn," Agrothrive LF; 2.5N-1.1P-1.2K; Agrothrive Inc., Morgan Hill, CA). The two fertilizer source treatments were applied at an equivalent total rate of $\mathrm{N}\left(56 \mathrm{~kg} \cdot \mathrm{ha}^{-1}\right.$ in 2012 and $90 \mathrm{~kg} \cdot \mathrm{ha}^{-1}$ in 2013) based on the percent $\mathrm{N}$ in the product as stated on the label.

${ }^{\mathrm{x}} P$ value provided unless nonsignificant (Ns; $P>0.05$ ).

Table 4. Effects of year, cultivar, and fertilizer source on floricane biomass dry weight (DW) per plant in organic blackberry grown at the North Willamette Research and Extension Center, Aurora, OR, 2012$13(\mathrm{n}=5)$.

\begin{tabular}{|c|c|c|c|}
\hline Treatments & \multicolumn{3}{|c|}{ Floricane biomass DW (kg/plant) } \\
\hline \multicolumn{4}{|c|}{ 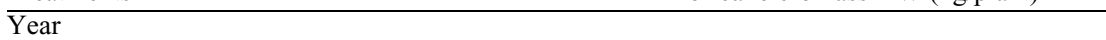 } \\
\hline 2012 & & 1.7 & \\
\hline 2013 & & 0.8 & \\
\hline Cultivar & 2012 & & 2013 \\
\hline Black Diamond (BD) & $1.3 \mathrm{~b}^{\mathrm{z}}$ & & $0.7 \mathrm{~d}$ \\
\hline Marion (M) & $2.0 \mathrm{a}$ & & $1.0 \mathrm{c}$ \\
\hline Fertilizer $^{\mathrm{y}}$ & $B D$ & & $M$ \\
\hline Fish & $1.1 \mathrm{c}$ & & $1.4 \mathrm{~b}$ \\
\hline Corn & $0.8 \mathrm{c}$ & & $1.6 \mathrm{a}$ \\
\hline \multicolumn{4}{|l|}{ Significance $^{\mathrm{x}}$} \\
\hline Year $(Y)$ & & NS & \\
\hline Cultivar (C) & & $<0.0001$ & \\
\hline Fertilizer $(\mathrm{F})$ & & NS & \\
\hline $\mathrm{Y} \times \mathrm{C}$ & & 0.0015 & \\
\hline $\mathrm{C} \times \mathrm{F}$ & & 0.0004 & \\
\hline $\mathrm{Y} \times \mathrm{C} \times \mathrm{F}$ & & NS & \\
\hline
\end{tabular}

${ }^{\mathrm{z}}$ Means followed by the same letter within the treatment or interaction are not significantly different $(P>0.05)$. ${ }^{\mathrm{y}}$ Fertilizer products used were: a blend of fish hydrolysate and fish emulsion combined with molasses ("fish," TRUE 402; 4N-0P-1.7K; True Organic Products, Inc., Spreckels, CA) and corn steep liquor ("corn," Agrothrive LF; 2.5N-1.1P-1.2K; Agrothrive Inc., Morgan Hill, CA). The two fertilizer source treatments were applied at an equivalent total rate of $\mathrm{N}\left(56 \mathrm{~kg} \cdot \mathrm{ha}^{-1}\right.$ in 2012 and $90 \mathrm{~kg} \cdot \mathrm{ha}^{-1}$ in 2013) based on the percent $\mathrm{N}$ in the product as stated on the label.

${ }^{\times} P$ value provided unless nonsignificant (Ns; $P>0.05$ ).

$\mathrm{NH}_{4}-\mathrm{N}$ was unaffected by cultivar or fertilizer source but was significantly higher in 2013 than 2012. Nakano et al. (2003) and Nakano and Uehara (2003) suggested that the $\mathrm{N}$ in corn steep liquor takes longer to be available to the plant as a result of the high amounts of organic $\mathrm{N}$ and small amounts of $\mathrm{NO}_{3}-\mathrm{N}$ and $\mathrm{NH}_{4}-\mathrm{N}$. The higher soil $\mathrm{NH}_{4}-\mathrm{N}$ level in 2013 may have been in response to the increased rate of $\mathrm{N}$ applied and because the mostly organic $\mathrm{N}$ applied in both fertilizers takes longer to go undergo nitrification (Burger and Jackson, 2003; Vanotti et al., 1995), $12.8 \pm 2.2$ weeks as estimated by Stanford and Smith (1972), depending on various soil factors.

Most primocane tissue nutrient concentrations (Table 6) were within the recommended levels for blackberry in Oregon (Hart et al., 2006). In 2012 and 2013, tissue N, P, K, $\mathrm{S}, \mathrm{Fe}, \mathrm{Mn}, \mathrm{Cu}$, and $\mathrm{Zn}$ concentrations were within the recommended standards, depending on cultivar $(2.3 \%$ to $3.0 \% \mathrm{~N}, 0.19 \%$ to $0.45 \% \mathrm{P}, 1.3 \%$ to $2.0 \% \mathrm{~K}, 0.1 \%$ to $0.2 \% \mathrm{~S}, 60$ to $250 \mathrm{ppm} \mathrm{Fe}, 50$ to $300 \mathrm{ppm} \mathrm{Mn,} 6$ to 20 ppm $\mathrm{Cu}$, and 15 to $50 \mathrm{ppm} \mathrm{Zn}$ ). Tissue $\mathrm{Mg}$ was within or below the recommended standards depending on year and cultivar $(0.3 \%$ to $0.6 \% \mathrm{Mg})$. Tissue $\mathrm{Ca}$ and $\mathrm{B}$ were below the recommended standard $(0.6 \%$ to $2.0 \% \mathrm{Ca}, 30$ to $70 \mathrm{ppm} \mathrm{B})$. Soils in the Pacific Northwest are often deficient in B (Hart et al., 2006). Boron deficiency in blackberry may result in a reduction in percent budbreak (Hart et al., 2006) and fruit weight (Kowalenko, 1981). Although B was applied in 2013, soil and tissue B concentrations declined. Additional studies are necessary to determine the efficacy of soil applications of B. Approved foliar B applications may be an alternative for organic blackberry production. 


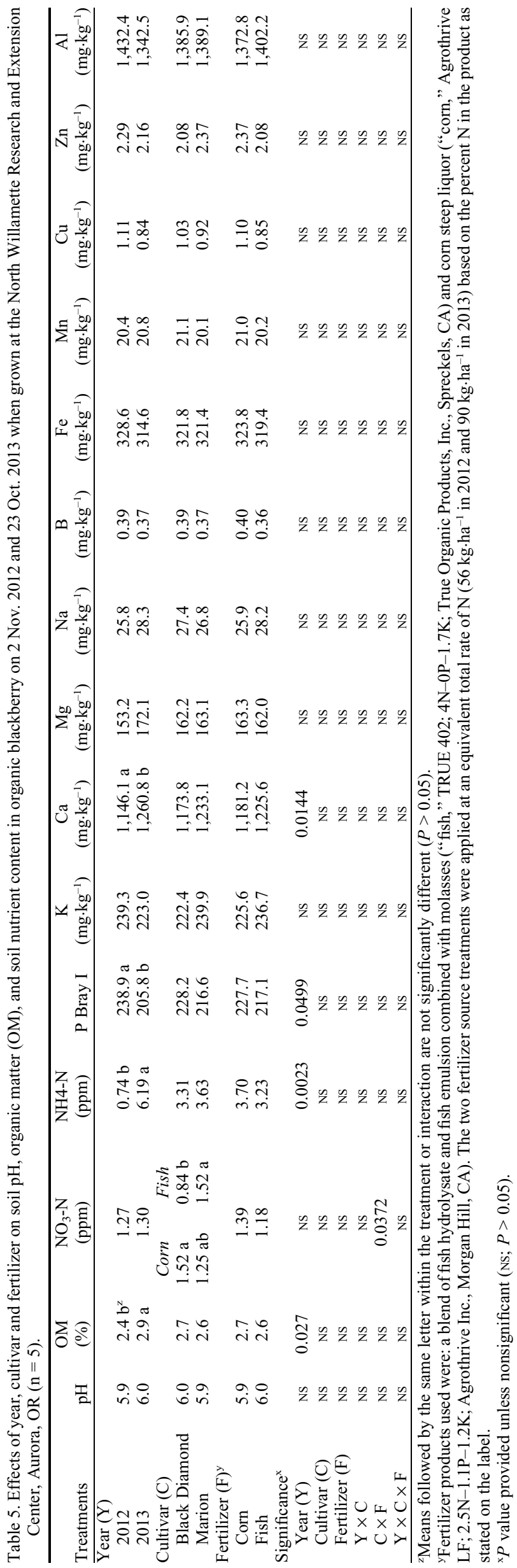

Primocane tissue nutrient concentration was unaffected by year for any of the nutrients tested (Table 6), although the yield was much greater in 2012 than in 2013 (Table 2). Although the high yield in 2012 reduced primocane growth, as mentioned previously, fertilization appeared to be adequate. There was a year $\times$ cultivar interaction for primocane leaf $\mathrm{S}, \mathrm{Cu}$, and $\mathrm{Zn}$, which did not differ among years in 'Marion', but was higher in 2013 than in 2012 in 'Black Diamond' (Table 6). Primocane leaf $\mathrm{K}$ and $\mathrm{Zn}$ concentration was higher in plants fertilized with fish than plants fertilized with corn. Additionally, there was a significant cultivar $\times$ fertilizer source interaction on leaf tissue $\mathrm{Mg}, \mathrm{S}$, and $\mathrm{B}$ concentration (Table 6). Primocane leaf Mg, $\mathrm{S}$, and $\mathrm{B}$ tended to be higher in 'Marion' when fertilized with fish compared with corn, whereas the opposite was found in 'Black Diamond'. The application of fish fertilizer, which had higher $\mathrm{K}$ content (Table 1), increased leaf $\mathrm{K}$, whereas the $25 \%$ greater rate of fertilizer $\mathrm{N}$ applied when using corn fertilizer had no significant effect on soil or tissue $\mathrm{N}$ content, possibly as a result of most of the additional $\mathrm{N}$ being in the organic-N form and being more slowly available to the plants (Andrews et al., 2010; Sullivan and Andrews, 2012). The higher rate of $\mathrm{N}$ applied also had no effect on yield, likely indicating that the $\mathrm{N}$ available at the lower rate of fish fertilizer was sufficient for blackberry. Additional studies are required to determine if there is a need for cultivar-specific nutrient recommendations in organic blackberry production.

Fertigation and drip system performance. Drip emitter flow rate was significantly affected by year but not by fertilizer source or drip maintenance treatment (Table 7). When the system was tested, before starting the fertigation treatments in 2011, the average water flow rate of the emitters was $2.2 \mathrm{~L} \cdot \mathrm{h}^{-1}$ (Fernandez-Salvador, 2014). In 2012, flow rate was reduced an average of $4.5 \%\left(0.1 \mathrm{~L} \cdot \mathrm{h}^{-1}\right)$ compared with 2011 and in 2013, there was an additional $19.0 \%\left(0.3 \mathrm{~L} \cdot \mathrm{h}^{-1}\right)$ reduction in emitter flow rate from the prior year (Table 7). Schwankl and McGourty (1992) found that flow rates were not drastically reduced after various applications of organic fertilizers (fish and poultry protein) in one fertigation season, similar to what we observed in our first season. However, we found that over a longer fertigation period ( 3 years), reduction in emitter performance was cumulative over time. There was a trend $(P=0.067)$ for flow rates to be higher when the fish fertilizer was fertigated in comparison with the corn fertilizer. The main reasons for drip emitter clogging are physical (particles), chemical (mineral interactions and solubility), and biological (growth of organisms), which are governed by a variety of factors (Boman and Ontermaa, 1994; Haman, 2011; Schwank1, 1992, 2008). Gilbert et al. (1982) suggested that bacteria in water may be affected by mineral and organic particles that contribute to population reproduction and growth, but they also concluded that biological clogging 


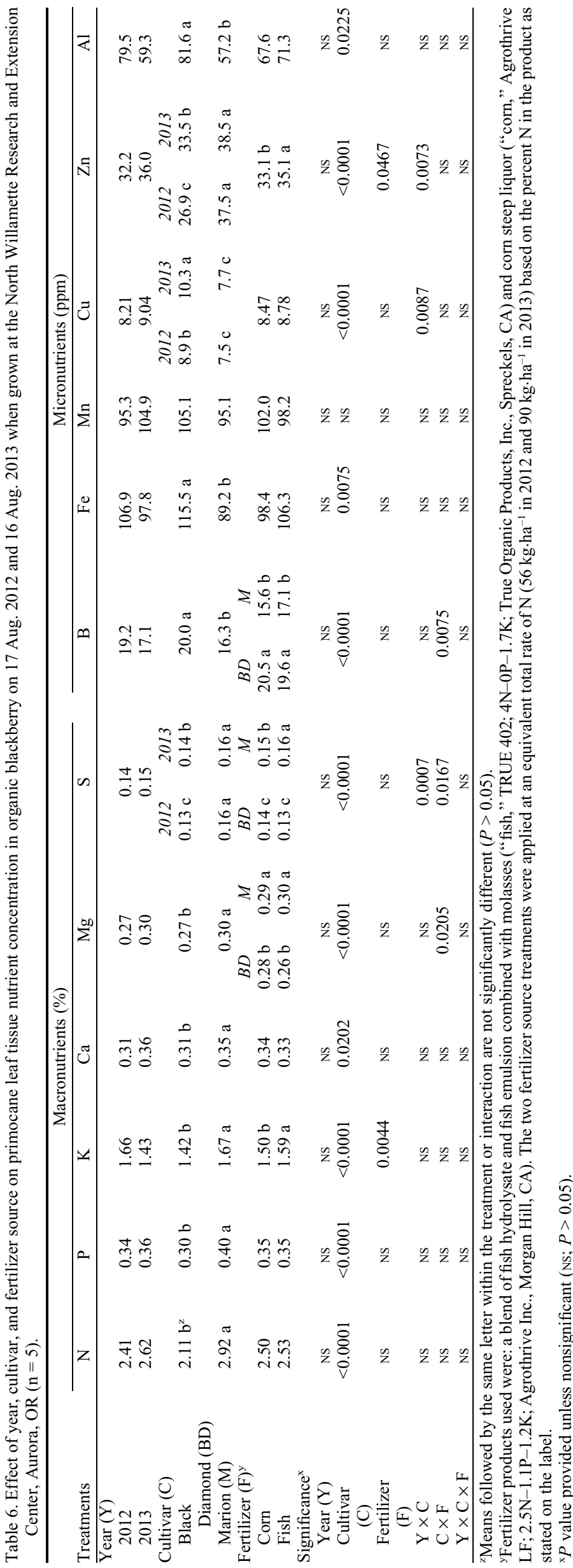

Table 7. Effects of fertigation with organic fertilizers and maintenance of the drip system on average drip emitter flow rates during the third and fourth years after planting blackberry at the North Willamette Research and Extension Center, Aurora, OR (2012-13; n = 3). ${ }^{\mathrm{z}}$

\begin{tabular}{lc}
\hline Yr/treatments & $\begin{array}{c}\text { Drip emitter } \\
\text { flow rate }\left(\mathrm{L} \cdot \mathrm{h}^{-1}\right)\end{array}$ \\
\hline Year (Y) & \\
2012 & 2.08 \\
2013 & 1.74 \\
Organic fertilizer (F) & \\
$\quad$ Corn steep liquor & 1.87 \\
$\quad$ Fish hydrolysate/emulsion & 1.94 \\
Drip maintenance (D) & \\
$\quad$ Flush & \\
$\quad$ No flush & 1.89 \\
Significance & 1.93 \\
Year (Y) & \\
Organic fertilizer (F) & 0.0068 \\
Drip maintenance (D) & $\mathrm{NS}$ \\
Y $\times$ F & $\mathrm{NS}$ \\
$\mathrm{F} \times \mathrm{D}$ & $\mathrm{NS}$ \\
$\mathrm{Y} \times \mathrm{F} \times \mathrm{D}$ & $\mathrm{NS}$ \\
\hline
\end{tabular}

${ }^{\mathrm{z}}$ The drip system was designed using drip tubing with $2-\mathrm{L} \cdot \mathrm{h}^{-1}$ integral pressure-compensating, continuously self-cleaning emitters spaced every $0.6 \mathrm{~m}$. The emitters had an average flow rate of $2.21 \mathrm{~L} \cdot \mathrm{h}^{-1}$ on $13 \mathrm{Apr} .2011$ (before any fertigation). ${ }^{\mathrm{y}}$ Both fertilizers were applied by fertigation through the drip system at an annual rate of $56.0 \mathrm{~kg} \cdot \mathrm{ha}^{-1} \mathrm{~N}$ in 2011 and 2012 and $89.7 \mathrm{~kg} \cdot \mathrm{ha}^{-1}$ $\mathrm{N}$ in 2013.

${ }^{x}$ Driplines with flush treatment were rinsed with water by opening a valve installed at the end of each tube section before each fertilization and flushed with water for $1 \mathrm{~min}$ before each volume measurement was taken during the season and also at the beginning and end of the irrigation period in 2012 and 2013.

${ }^{\mathrm{w}} P$ value provided unless nonsignificant (Ns; $P>$ $0.05)$.

was minimal in 4 years of operation and that the main reasons for drip clogging were physical and biological slime deposits, which could also be possible reasons for the water volume reduction in the present study. Additional research is needed to determine the possible causes for clogging in organically managed fertigated systems.

\section{Conclusions}

Using the current standards for blackberry (Hart et al., 2006), the liquid corn and fish organic fertilizers applied, although differing in macro- and micronutrient content, supplied sufficient nutrients to meet plant needs with the exception of $\mathrm{Ca}$ and $\mathrm{B}$. Both fertilizers could be applied through the drip, but emitter performance was reduced over time. For perennial organic crops, flushing of the fertigation system should be conducted on a regular basis to reduce the possibility of residue accumulation at the end of the lines and to prevent emitter clogging over time. Further research is needed to determine the cause of the reduction in emitter flow performance and the relation to organic fertilizers and possible causes for clogging. As expected, 'Black Diamond' had greater total yield and average fruit weight than 'Marion'. 
Fertilizer source had no effect on yield, although there were some minor effects on fruit quality.

\section{Literature Cited}

Andrews, N., D. Sullivan, J. Julian, and K. Pool. 2010. OSU organic fertilizer and cover crop calculator. 13 Aug. 2014. <http://smallfarms. oregonstate.edu/calculator $>$.

Archbold, D.D., J.G. Strang, and D.M. Hines. 1989. Yield component responses of hull thornless blackberry to nitrogen and mulch. HortScience 24:604-607.

Bell, N.C., B.C. Strik, and L.W. Martin. 1995. Effect of primocane suppression date on 'Marion' trailing blackberry. I. Yield components. J. Amer. Soc. Hort. Sci. 120:21-24.

Boman, B. and E. Ontermaa. 1994. Citrus microsprinkler clogging: Cost, causes, and cures. Proc. Fla. State Hort. Soc. 107:39-47.

Burger, M. and L.E. Jackson. 2003. Microbial immobilization of ammonium and nitrate in relation to ammonification and nitrification rates in organic and conventional cropping systems. Soil Biol. Biochem. 35:29-36.

Bushway, L., M. Pritts, and D. Handley. 2008. Raspberry and blackberry production guide for the northeast, midwest, and eastern Canada. Cornell University, NRAES-35, Ithaca, NY.

Chaplin, M.H. and L.W. Martin. 1980. The effect of nitrogen and boron fertilizer applications on leaf levels, yield and fruit size of the red raspberry. Commun. Soil Sci. Plant Anal. 11:547-556.

Cortell, J.M. and B.C. Strik. 1997. Effect of floricane number in 'Marion' trailing blackberry. II. Yield components and dry mass partitioning. J. Amer. Soc. Hort. Sci. 122:611-615.

Dahnke, W.C. 1990. Testing soils for available nitrogen, p. 120-140. In: Westerman, R.L. (ed.). Soil testing and plant analysis. Soil Sci. Soc. Amer. Book Series 3. SSSA, Madison, WI.

Fernandez-Salvador, J.A. 2014. Nutrient management of blackberry cultivars grown in organic production systems. Master's thesis, Oregon State Univ., Corvallis, OR. 1 July 2014. <http:// ir.library.oregonstate.edu/xmlui/bitstream/handle/ 1957/49147/Fernandez-SalvadorJavierA2014.pdf? sequence $=3>$.

Fernandez-Salvador, J.A., B.C. Strik, and D. Bryla. 2015. Response of blackberry cultivars to fertilizer source during establishment in an organic fresh market production system. HortTechnology (In press).

Finn, C., B. Yorgey, B.C. Strik, H.K. Hall, R.R. Martin, and M. Qian. 2005. 'Black Diamond' thornless trailing blackberry. HortScience 40 : 2175-2178.

Fonte, S.J., T. Winsome, and J. Six. 2009. Earthworm populations in relation to soil organic matter dynamics and management in California tomato cropping systems. Appl. Soil Ecol. 41:206-214.

Gärdenäs, A.I., J.W. Hopmans, B.R. Hanson, and J. Šimůnek. 2005. Two-dimensional modeling of nitrate leaching for various fertigation scenarios under micro-irrigation. Agr. Water Mgt. 74:219-242.

Gaskell, M. and R. Smith. 2007. Nitrogen sources for organic vegetable crops. HortTechnology 17:431-441.

Gavlak, R.G., D.A. Horneck, and R.O. Miller. 1994. Soil and plant tissue reference methods for the western region. Univ. Alaska Western Reg. Publ. 125.

Gilbert, R.G., F.S. Nakayama, D.A. Bucks, O.F. French, K.C. Adamson, and R.M. Johnson.
1982. Trickle irrigation: Predominant bacteria in treated Colorado River water and biologically clogged emitters. Irrig. Sci. $3: 123-132$

Haman, D.Z. 2011. Causes and prevention of emitter plugging in microirrigation systems. Flor. Coop. Ext. Serv. Bul. 258.

Hanson, B.R., J. Simůnek, and J.W. Hopmans. 2006. Evaluation of urea-ammonium-nitrate fertigation with drip irrigation using numerical modeling. Agr. Water Mgt. 86:102-113.

Harkins, R., B.C. Strik, and D. Bryla. 2013. Weed management practices for organic production of trailing blackberry: I. Plant growth and early fruit production. HortScience 48:11391144.

Harkins, R., B.C. Strik, and D. Bryla. 2014. Weed management practices for organic production of trailing blackberry. II. Accumulation and loss of biomass and nutrients. HortScience 49:35-43.

Hart, J., B.C. Strik, and H. Rempel. 2006. Caneberries. Nutrient management guide. Ore. State Univ. Ext. Serv., EM8903-E.

Julian, J.W., C.F. Seavert, B.C. Strik, and D. Kaufman. 2009. Berry economics: Establishing and producing 'Marion' blackberries in the Willamette Valley, Oregon. Ore. St. Univ. Ext. Serv. EM 8773.

Keller and Heckman, LLP. 2006. Assessment plan for corn steep liquor (CAS \#66071-941) in accordance with the USEPA high production volume chemical challenge program. The Corn Refiners Association, Washington, DC.

Kowalenko, C.G. 1981. Response of raspberries to soil nitrogen and boron applications. Commun. Soil Sci. Plant Anal. 12:11511162.

Kuepper, G. 2003. Manures for organic crop production. National Center for Appropriate Technology. Fayetteville, AR. 4 Mar. 2014. <https:// attra.ncat.org/attra-pub/summaries/summary.php? pub $=182>$.

Kuepper, G.L., H. Born, and J. Bachmann. 2003. Organic culture of bramble fruits. National Center for Appropriate Technology. Fayetteville, AR. 4 Mar. 2014. <https://attra.ncat.org/ attra-pub/summaries/summary.php?pub=15>.

Larco, H., B.C. Strik, D.R. Bryla, and D.M. Sullivan. 2013. Mulch and fertilizer management practices for organic production of highbush blueberry. I: Plant growth and allocation of biomass during establishment. HortScience 48:1250-1261.

Malik, H., D.D. Archbold, and C.T. MacKown. 1991. Nitrogen partitioning by 'Chester Thornless' blackberry in pot culture. HortScience 26:1492-1494.

McLean, E.O. 1982. Soil pH and lime requirement, p. 199-223. In: Page, A.L. (ed.). Methods of soil analysis, Part 2. Agronomy monograph 9. 2nd Ed. ASA and SSSA, Madison, WI.

Mehlich, A. 1984. Mehlich-3 soil test extractant: A modification of Mehlich-2 extractant. Commun. Soil Sci. Plant Anal. 15:1409-1416.

Mikkelsen, R. and T.K. Hartz. 2008. Nitrogen sources for organic crop production. Better Crops. 92:16-19.

Mohadjer, P., B.C. Strik, B.J. Zebarth, and T.L. Righetti. 2001. Nitrogen uptake, partitioning and remobilization in 'Kotata' blackberry in alternate-year production. J. Hort. Sci. Biotechnol. 76:700-708.

Nakano, A. and Y. Uehara. 2003. Effects of corn steep liquor (CSL) and methane fermented liquid cattle waste (MFC) application in fertigation soil culture on growth and yield of muskmelon (Cucumis melo L.) fruit. Hort. Res. 2:175-178.

Nakano, A., Y. Uehara, and A. Yamauchi. 2001. Establishment of organic fertigation system using CSL (corn steep liquor): Effect of CSL application on tomato (Lycopersicon esculentum Mill.) growth, yield, quality and soil chemical property. Jpn J. of Soil Sci. Plant Nutr. 72:505-512.

Nakano, A., Y. Uehara, and A. Yamauchi. 2003. Effect of organic and inorganic fertigation on yields, $\delta 15 \mathrm{~N}$ values, and $\delta 13 \mathrm{C}$ values of tomato (Lycopersicon esculentum Mill. cv. Saturn). Plant and Soil Sci. 255:343-349.

Naraguma, J. and J.R. Clark. 1998. Effect of nitrogen fertilization on 'Arapaho' thornless blackberry. Commun. Soil Sci. Plant Anal. 29:2775-2783.

National Agricultural Statistical Service. 2013. Oregon berry production. U.S. Dept. Agric., Natl. Agr. Stat. Serv., Portland, OR.

National Organic Standards Board Crops Committee. 2011. Corn steep liquor proposed synthetic/ nonsynthetic determination. 15 July 2014 $<$ http://www.ams.usda.gov/AMSv1.0/getfile? dDocName $=$ STELPRDC5089617> .

Nelson, E. and L.W. Martin. 1986. The relationships of soil-applied $\mathrm{N}$ and $\mathrm{K}$ to yield and quality of 'Thornless Evergreen' blackberry. HortScience 21:1153-1154.

Nelson, D.W. and L.E. Sommers. 1996. Total carbon, organic carbon and organic matter, $p$. 961-1010. In: Bartels, J.M. (ed.). Methods of soil analysis: Part 3: Chemical methods. 3rd Ed. ASA and SSSA Book Series 5, Madison, WI.

OMRI. Organic Materials Review Institute home page. 2013. 12 Dec. $2013<$ https://www.omri.org/>

Schwank1, L. 1992. Drip irrigation filtration and water treatment to prevent clogging. UC Davis and UC Kearney Ag. Center, UC Cooperative Extension, Davis, CA.

Schwankl, L. 2008. Causes of clogging: Overview of maintenance needs, p. 3-9. In: Schwankl, L., B. Hanson, and T. Prichard (eds.). Maintaining micro irrigation systems. University of California, Oakland, CA.

Schwankl, L.J. and G. McGourty. 1992. Organic fertilizers can be injected through low volume irrigation systems. Calif. Agr. (SeptemberOctober):21-23.

Sideman, E. 2007. Providing nitrogen to organic crops. Maine Organic Farmers and Gardeners Association Fact Sheet \#8.

Siriwoharn, T., R.E. Wrolstad, C.E. Finn, and C.B. Pereira. 2004. Influence of cultivar, maturity, and sampling on blackberry (Rubus L. Hybrids) anthocyanins, polyphenolics, and antioxidant properties. J. Agr. Food Chem. 52:8021-8030.

Spiers, J.M. and J.H. Braswell. 2002. Influence of $\mathrm{N}, \mathrm{P}, \mathrm{K}, \mathrm{Ca}$, and $\mathrm{Mg}$ rates on leaf macronutrient concentration of 'Navaho' blackberry. Acta Hort. 585:659-663.

Stanford, G. and S.J. Smith. 1972. Nitrogen mineralization potentials of soils. Soil Sci. Soc. Amer. J. 36:465-472.

Strik, B.C., D. Bryla, H. Larco, and J. Julian. 2012. Organic highbush blueberry production systems research-Management of plant nutrition, irrigation requirements, weeds and economic sustainability. Acta Hort. 933: 215-220.

Strik, B.C. and C.E. Finn. 2012. Blackberry production systems - A worldwide perspective. Acta Hort. 946:341-348. 
Sullivan, D.M. and N.D. Andrews. 2012. Estimating plant-available nitrogen release from cover crops. Ore. State Univ. Ext. Serv., PNW 636.

Vanotti, M.B., S.A. Leclerc, and L.G. Bundy. 1995. Short-term effects of nitrogen fertilization on soil organic nitrogen availability. Soil Sci. Soc. Amer. J. 59:1350-1359.
Young, J.E., X. Zhao, E.E. Carey, R. Welti, S.S. Yang, and W. Wang. 2005. Phytochemical phenolics in organically grown vegetables. Mol. Nutr. Food Res. 49:1136-1142.

Zhang, M., S. Sparrow, P.J. Bechtel, and A. Pantoja. 2007. Characteristics of nitrogen and phosphorous release from fish meals and fish hydrolysate in subartic soils. J. Environ. Monit. Rest. 3:262-275.
Zhao, X., E. Chambers, IV, Z. Matta, T.M. Loughin, and E.E. Carey. 2007. Consumer sensory analysis of organically and conventionally grown vegetables. J. Food Sci. 72:S87-S91.

Zibilske, L.M. 2010. Permeability of fabric ground covers to organically-derived nutrients. Intl. J. Fruit Sci. 10:109-122. 